\title{
Extraction Nanoparticles from Chicory for Cooling Purposes of Photovoltaic Solar Cell with Nanofluid
}

\author{
M.Abd Elshokary ${ }^{1}$, Mousa M. Mohamed ${ }^{2}$, 2Rifai R. ${ }^{3}$, M. F Azzazy ${ }^{3}$
}

1- Research- Institute of Environmental Studies and Research

2- Faculty of Engineering, Menoufia University, Shebin El-Kom,

3- Environmental Studies and Research Institute, University of Sadat City, Egypt

\section{Abstract}

Chicory or the so-called in Egypt Al-serees is found in a large quantities of agricultural clover and vegetables. The present study investigates the methanolic extract $70 \%$ of Cichorium intybus $L$ belonging to family Asteraceae. Data obtained from the elemental analysis revealed the presence of 23 elements. The major detected elements are Sodium (Na) 159.59 ppm, potassium (K) 19.29 ppm, Calcium (Ca) 8.68 ppm, Magnesium (Mg) $6.88 \mathrm{ppm}$ and Aluminium (Al) $3.11 \mathrm{ppm}$ respectively. The metallic nanoparticles are traditionally synthesized by wet chemical techniques with potassium chloride. The formation of potassium chloride nanoparticles was confirmed by X-Ray Diffraction, (XRD). The XRD pattern indicates that the nanoparticles had cubic structure. The XRD analysis of potassium chloride $(\mathrm{KCl})$ nanoparticles have five peaks at $28.39,40.58,50.25,58.75$ and 66.47 angles. At $28.39=2 \theta$, the curve has the extra highest peak. The average crystallite size for $\mathrm{KCl}$ as observed from XRD spectral analysis was found to be $20 \mathrm{~nm}$, which is in agreement with the Transmission Electron Microscpe (TEM) analysis. The Scanning Electron Microscope (SEM) analysis shows the spheric potassium chloride and other minerals nanoparticles.The potassium chloride and other elements nanoparticles may be used to improve the performance of photovoltaic solar cell. The selection of chicory (Al-serees ) is due to a cost effective and environmental friendly technique

Key words : cooling of photovoltaic solar cell, nanofluid, potassium chloride nanoparticles, stored energy

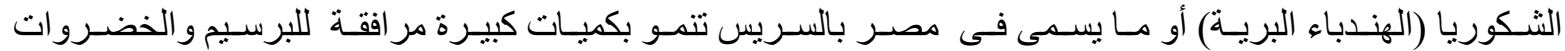

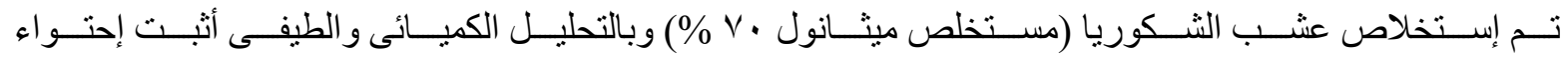

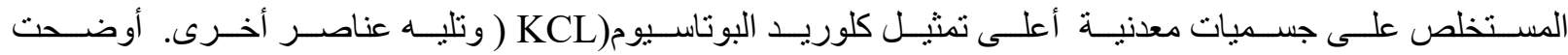

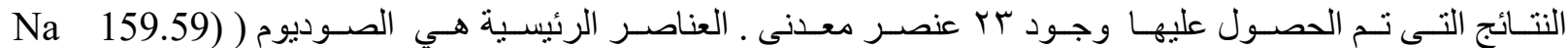

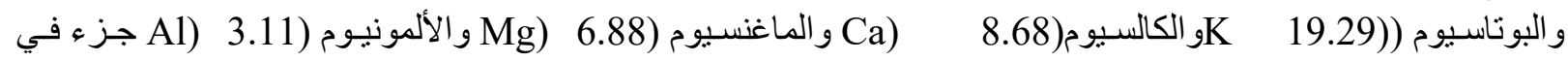

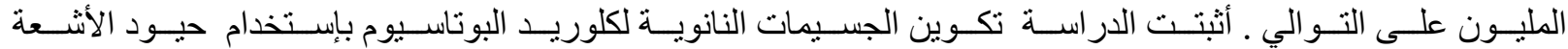

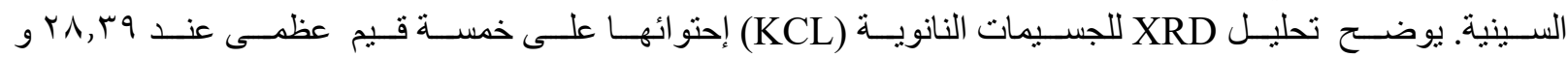




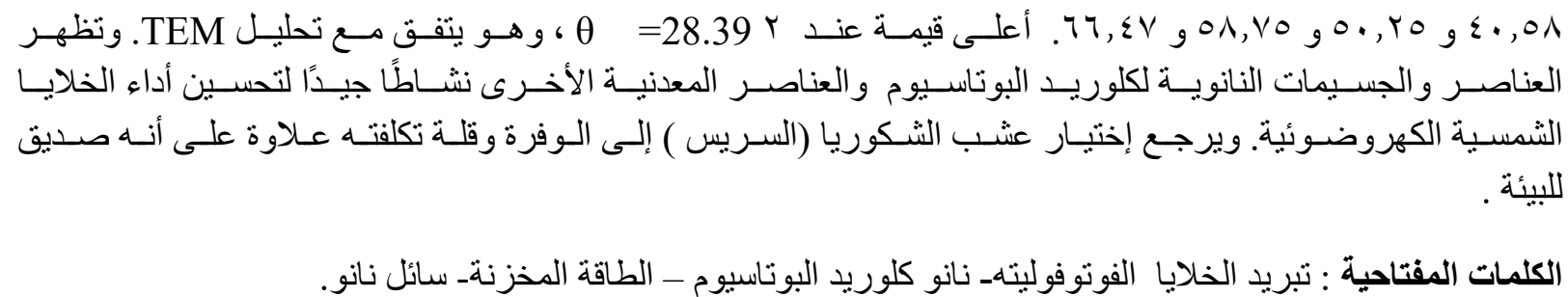

\section{Introduction}

Chicory or so-called in our country Egypt Al-serees, is found in a large number of agricultural clover and vegetable as shown in Fig.1. Although the plant is not in the cultivation of Alfalfa because it takes place from Alfalfa, and the farmer wants Alfalfa widely to fatten the cattle. The Chicory has medical benefits[1]. Large Serees is useful for patients with liver disease, diabetes mellitus and diarhea. Also, Al-seris is useful for kidneys as it burns fat and is used for slimming and its fiber is beneficial for the colon [2]. It is most likely known by the Egyptians as a medicinal plant [3] and used as a vegetable crop by ancient Greeks and the Romans [4]. Chicory (C. intybus L.) belongs to the family Asteraceae, a very large family with approximately 23,000 species subdivided into 1,535 genera grouped into three subfamilies: Barnadesioideae, Cichorioideae, and Asteroideae [5]. Chicory root has a levels. This activity is attributed to high amounts of the inulin-type fructans that slow down carbohydrate digestion and glucose absorption in the gastrointestinal tract [6]. Chicory plants also produce a variety of other bioactive secondary metabolites, including caffeoylquinic acids and caffeic acid derivatives as major phenolic constituents [7]. Chicory is a perennial herb in the Asteraceae (Compositae) family edible as a vegetable crop and animal forage [8,9]. Contemporary applications for chicory leaves include salad, whereas root grounds are added to flavor coffee $[8,10]$. Inulin content has also made chicory root a common soluble fiber additive in the food industry $[11,12]$. The aim of the present study is to prepare a nanofluid using in Photovoltic solar cell cooling.

\section{MATERIALS AND METHODS}

This study was conducted at Environmental Studies and Research Institute University of Sadat City - Sadat City - Menoufia-Egypt

\subsection{Nanofluid Extraction from Chicory}

This part includes chicory preparation to be used as diluted Nanofluid solution in the PV cooling system. Four methods were chosen for testing extracted ash properties. These four methods are chemical analyses carried out by Inductive Coupled PlasmaMass Spectra (ICP-MS), That is a powerful tool for analyzing trace metals in environmental samples. A large range of elements can be detected using an ICP-MS. The benefits of using plasma compared to other ionization methods, such as flame ionization, are that ionization occurs in a chemically inert environment, preventing oxide formation, and ionization is more complete. Also, the temperature profile of the 
torch is relatively uniform, reducing self absorption effects. The process can be broken down to four stages; sample introduction, ICP-MS [13], the samples described below were tested in environmental and food biotechnology laboratory by using NIST traceable reference equipment and materials (Merck KgaA, ICP Multi-Elements Standard Solution IV, LOT \# HC379062) in accordance with ISO/IEC 17025:2005 requirements and the methods referenced below meet ISO/IEC 17025:2005 and accreditation requirements, Sadat University, Egypt.

The mineralogical composition investigated by using X-Ray Difractometer (XRD) Bruker D2 Phaser $2^{\text {nd }}$ Gen, Generator Current $(\mathrm{mA}) 10 \mathrm{~m}$, Wavelength Alpha 1.54060 $\mathrm{A}^{\circ}$, start angle 10 and end angle 70 , crystal size is calculated by scherrer equation $[14,15]$. The samples described below were tested in environmental geology testing laboratory by using NIST traceable reference equipment and materials in accordance with ISO/IEC 17025:2017 requirements and the methods referenced below meet ISO/IEC 17025:2017 and accreditation requirements, Sadat University, Egypt Scanning Electron Microscope (SEM) analysis. The specimens were examined with a JEOL/EO-JSM-6510 LV scanning electron microscope (Jeol JEM-2100 Scanning Electron Microscope) at Electron Microscpe,Mansoura University, Egypt and Transmission Electron Microscpe (TEM) analysis, Perfusion or immersion fixation of the tissue using a modified solution [16]: $2.5 \%$ buffered glutaraldehyde $+2 \%$ paraformaldehyde in $0.1 \mathrm{M}$ sodium phosphate buffer $\mathrm{pH} 7.4$, leave tissue overnight at $4^{\circ} \mathrm{C}$, wash $3 \times 15$ minutes (min.) in $0.1 \mathrm{M}$ sodium phosphate buffer $+0.1 \mathrm{M}$ Sucrose , postfix $90 \mathrm{~min}$. in $2 \%$ sodium phosphate buffered osmium tetroxide $\mathrm{pH} 7.4$, wash $3 \mathrm{x}$ $15 \mathrm{~min}$ in $0.1 \mathrm{M}$ sodium $\mathrm{p}$, after drying for $\sim 15 \mathrm{~min}$ sections may be investigated using a transmission electron microscope. Ultrathin sections were observed at $160 \mathrm{kV}$ using a JEOL JEM -2100 at Electron Microscpe Unit, Mansoura University, Egypt.

\subsubsection{Collection of fresh chicory}

Fresh chicory plant used in the study was collected from Nile Delta Clay soil in Menouf, Menoufia, Egypt. Then dried according to the standard condition (under shade at low humidity at room temperature). Fresh chicory were identified and authenticated by Dr. Mohamed Azzazy, Environmental Studies and Researches Institute, University of Sadat City, Egypt.

\subsubsection{Preparation of chicory extract}

To prepare the chicory extract, the plant was shade-dried completely, ground to powder

Figure 2. 


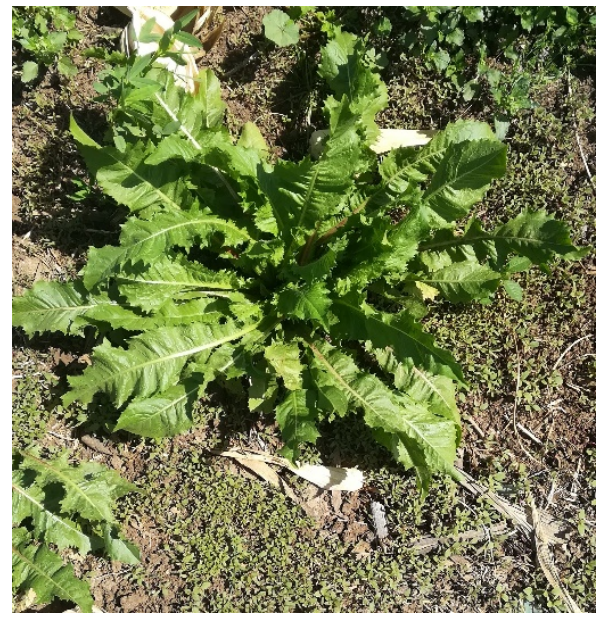

Figure 1: Fresh chicory

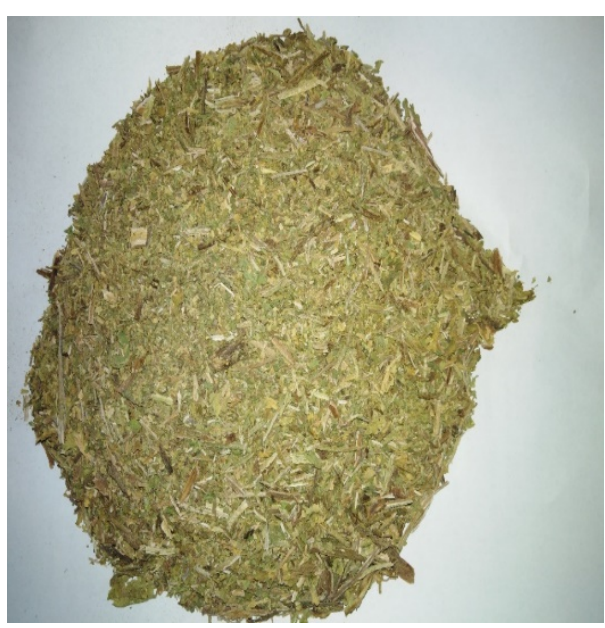

Figure 2: Chicory powder

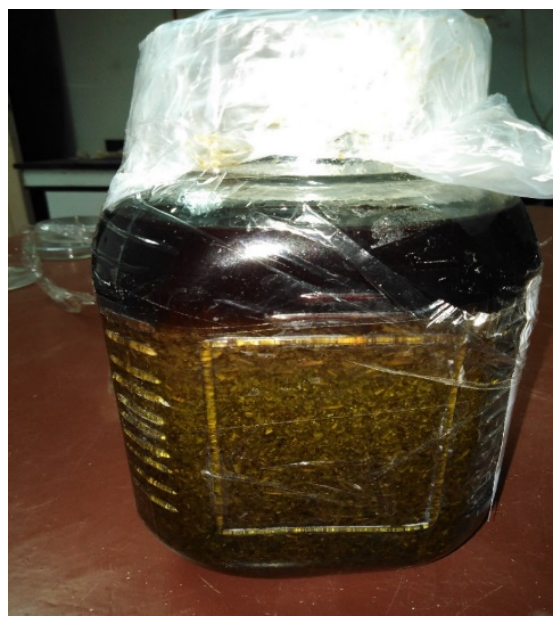

Figure 3: Soaked chicory

The Chicory powder was drenched in ethanol with concentration of $70 \%$ [17]. The Chicory alcohol mixture was left for 7 days in a glass jar before its filtration using. Figure 3 shows the soaked chicory. Then the solvent was passed through a Whatman paper filter to a flask. After that the solvent was vaporized slowly, and the highdensity liquid extract was put in the Petri dish and dried at room temperature. Figure 4 shows the chicory extract in Petri dish. We put high-density chicory extract liquid in a muffle furnace at $450^{\circ} \mathrm{C}$ to convert it to ash. Figure 5 shows the chicory extract ash.

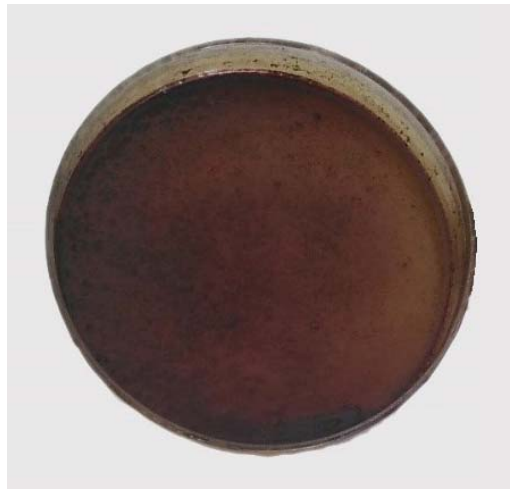

\subsubsection{Nanofluid}

Figure 4:

extract

5:

extract

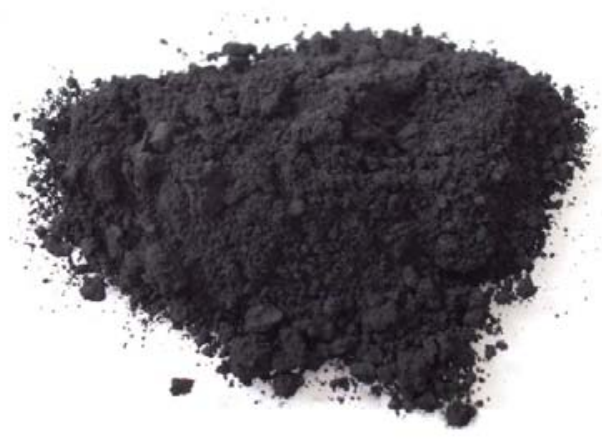

Chicory

Figure

Chicory

ash

The used nanofluid also was made with the desired specs. To prepare the Nanofluid, water was mixed with the required mass grinded solid material, i.e. nanoparticles, to attain the required concentration (i.e. $0.01 \%$ or above by weight). The main advantages of Nanofluids are greater thermal conductivity and somewhat greater heat capacity [18]. Nanofluids have intensified thermophysical properties, such as thermal conductivity, viscosity and convective heat transfer coefficients, compared with conventional fluids [19].

\section{3- RESULTS AND DISSCUTION}

\subsection{Elemental Composition Analysis Inductive Coupled Plasma-Mass Spectra (ICP-MS) of Chicory Extract (ppm)}


Elemental composition analysis revealed presence of 23 elements, the major elements are $\mathrm{Na} 159.59$ ppm, K 19.29 ppm, $\mathrm{Ca} 8.68 \mathrm{ppm}, \mathrm{Mg} 6.88 \mathrm{ppm}$ and $\mathrm{Al}$ $3.11 \mathrm{ppm}$. Table.1 shows the result obtained from the elements' analysis that was carried out on the chicory extract.

\begin{tabular}{|c|c|c|c|c|c|c|c|c|c|c|c|c|}
\hline Element & $\mathbf{N a}$ & $\mathbf{K}$ & $\mathbf{C a}$ & Mg & Al & $\mathrm{Cr}$ & Zn & $\mathbf{F e}$ & $\mathrm{Sr}$ & $\mathbf{B i}$ & $\mathbf{T i}$ & Mn \\
\hline $\begin{array}{l}\text { Weight(pp } \\
\text { m) }\end{array}$ & $\begin{array}{l}159.5 \\
9\end{array}$ & $\begin{array}{l}19.2 \\
9\end{array}$ & $\begin{array}{l}8.6 \\
8\end{array}$ & 6.88 & 3.11 & 2.27 & 1.20 & 0.87 & 0.85 & 0.63 & 0.56 & $\begin{array}{l}0.3 \\
3\end{array}$ \\
\hline Element & Ba & $\mathbf{P b}$ & In & $\mathrm{Cu}$ & B & $\mathbf{N}$ & $\mathbf{L i}$ & Ga & Ag & Co & Cd & \\
\hline $\begin{array}{l}\text { Weight(pp } \\
\text { m) }\end{array}$ & 0.32 & 0.24 & $\begin{array}{l}0.1 \\
5\end{array}$ & $\begin{array}{l}0.13 \\
8\end{array}$ & $\begin{array}{l}0.08 \\
8\end{array}$ & $\begin{array}{l}0.08 \\
5\end{array}$ & $\begin{array}{l}0.03 \\
5\end{array}$ & $\begin{array}{l}0.03 \\
1\end{array}$ & $\begin{array}{l}0.02 \\
8\end{array}$ & $\begin{array}{l}0.92 \\
7\end{array}$ & $\begin{array}{l}0.00 \\
6\end{array}$ & \\
\hline
\end{tabular}

Table.1: Elements composition of chicory extract

\subsection{X-Ray Diffraction (XRD) Analysis}

The crystalline nature of nanoparticles was confirmed by X-ray crystallography. The XRD pattern of the chicory extract ash is shown in Figure 6. The XRD pattern indicates that the only mineral in its composition is KCL (sylvite), the result crystal size shown had cubic structure. The XRD analysis of chicory extract ash contains KCL nanoparticles which has five peaks. The average crystallite size for sylvite calculated from XRD pattern is $20 \mathrm{~nm}$. 


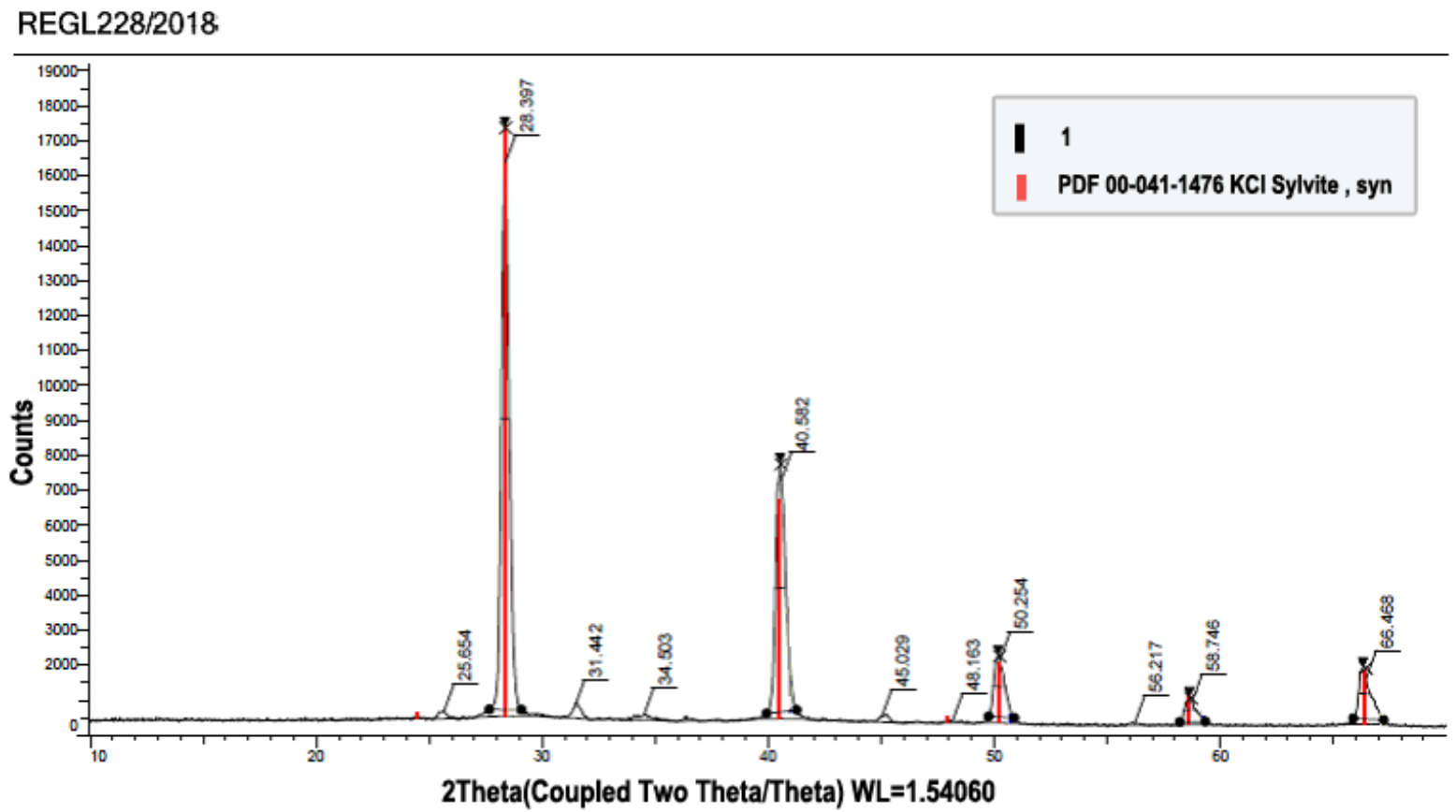

Figure 6: XRD analysis of chicory extract ash.

\subsection{Scanning Electron Microscope (SEM) Analysis}

SEM technique was employed to visualize the size and shape of chicory extract , Figure 7 show the $5 \mu \mathrm{m}$ and $10 \mu \mathrm{m}$ SEM photographs of the chicory extract ash respectively.

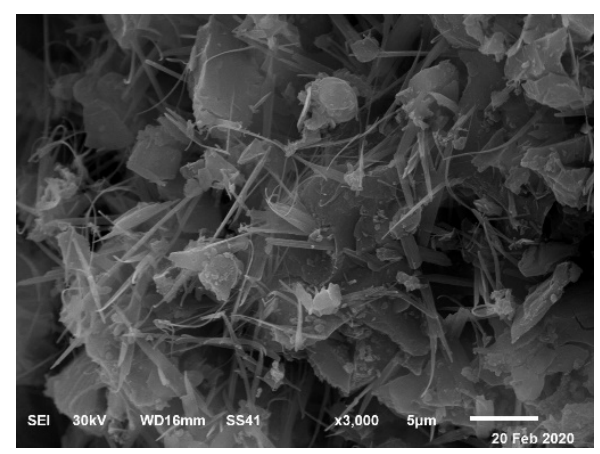

(a)

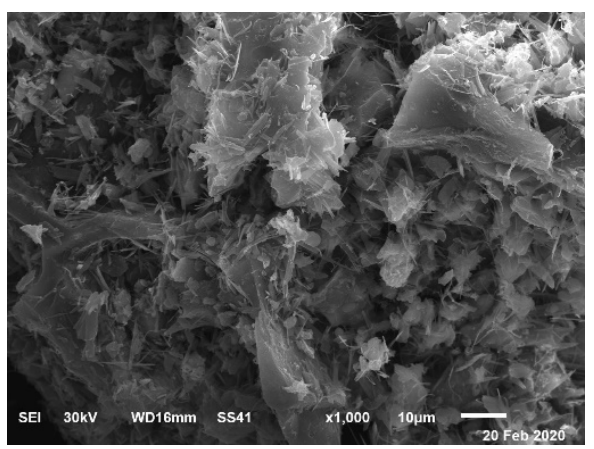

(d)

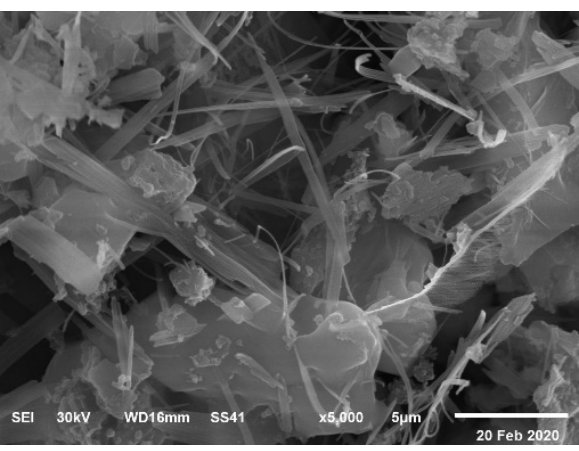

(b)

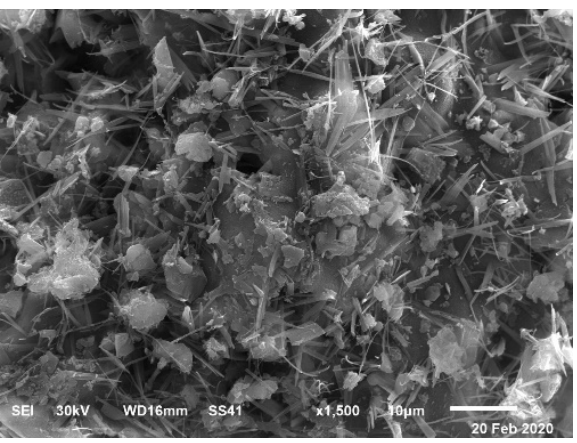

(e)

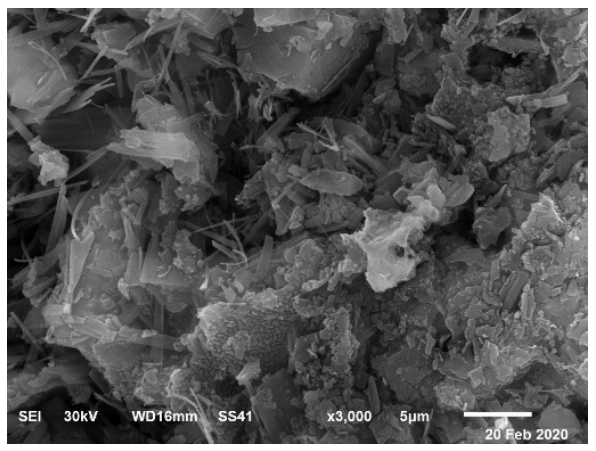

(c)

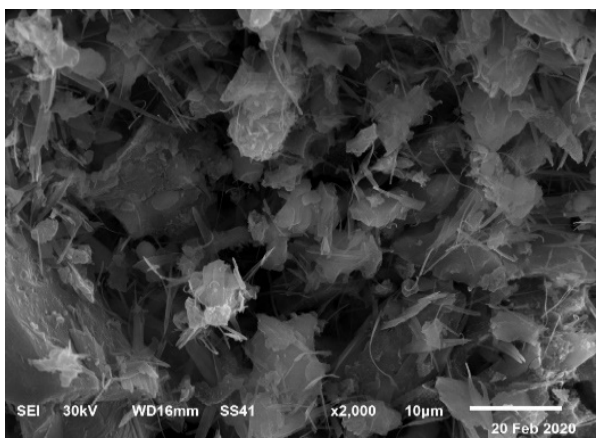

(f) 
Figure 7: SEM micrograph of chicory extract ash at $5 \mu \mathrm{m}$ and $10 \mu \mathrm{m}$. a,b,c,d,e and f represents different shaps at $5 \mu \mathrm{m}$ and $10 \mu \mathrm{m}$ micrography.

\subsection{Transmission Electron Microscpe (TEM) analysis}

TEM analysis shapes clearly show that the chicory extract ash has an appropriate diameter in the range of the nano scale, Figure $8 \mathrm{a}, \mathrm{b}$ and $\mathrm{c}$ represents the $50 \mathrm{~nm}$ of TEM micrograph of chicory extract ash, which explains nanoparticles with an average grain size of about $(3.15-20.73) \mathrm{nm}$. Figure $8 \mathrm{~d}$,e and $\mathrm{f}$ represents the $100 \mathrm{~nm}$ of TEM micrograph of chicory extract ash, which explains nanoparticles with an average grain size of about $(5.12$ - 22.18) nm. Figure 8 represents the $200 \mathrm{~nm}$ of TEM micrograph of chicory extract ash.

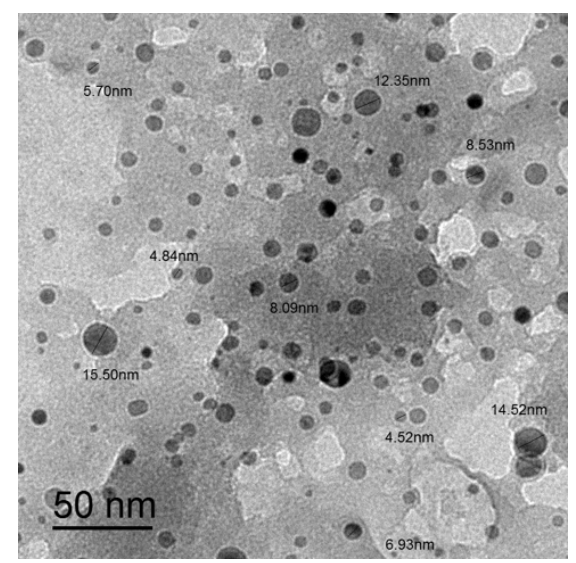

(a)

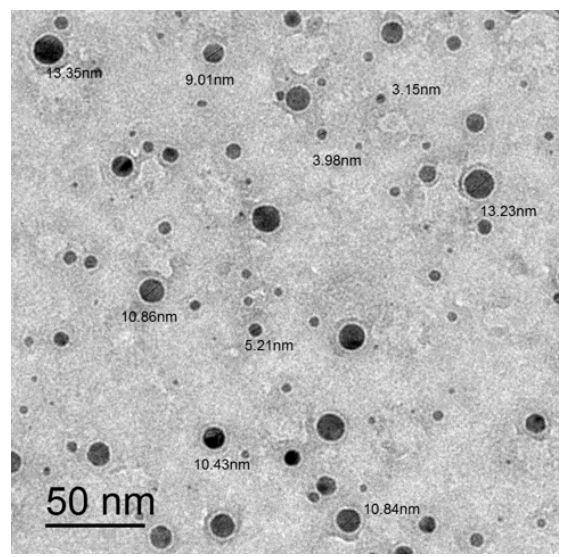

(b)

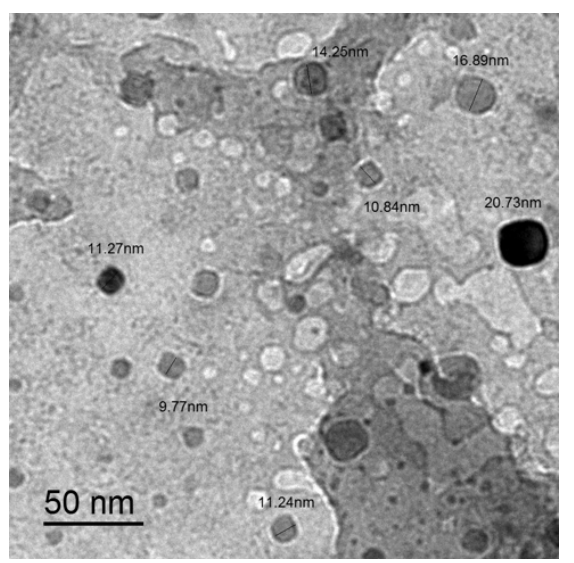

(c)

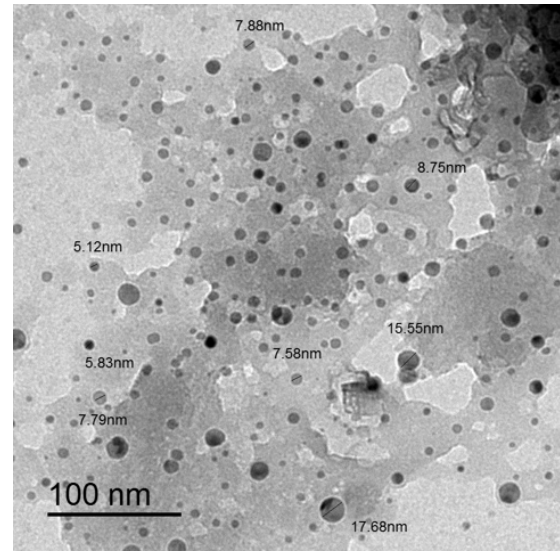

(d)

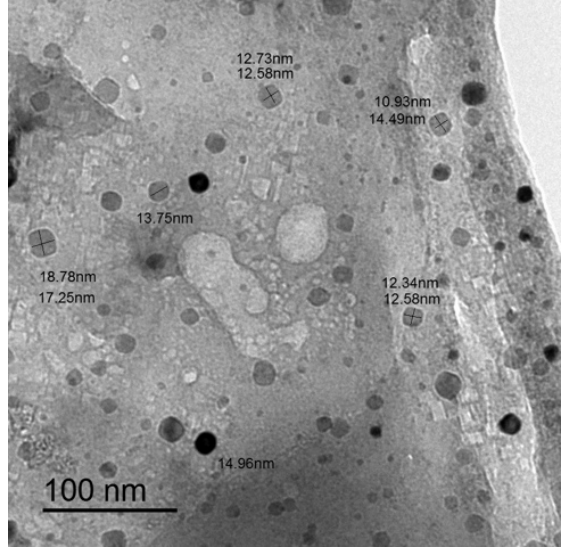

(e)

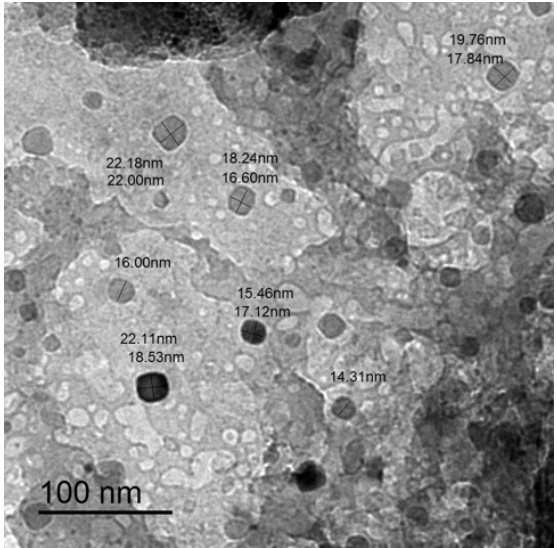

(f) 


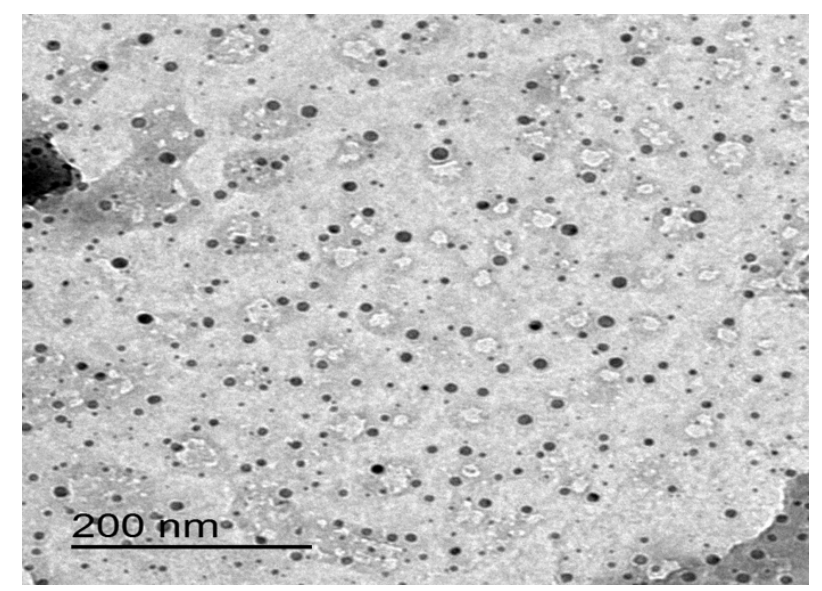

(g)

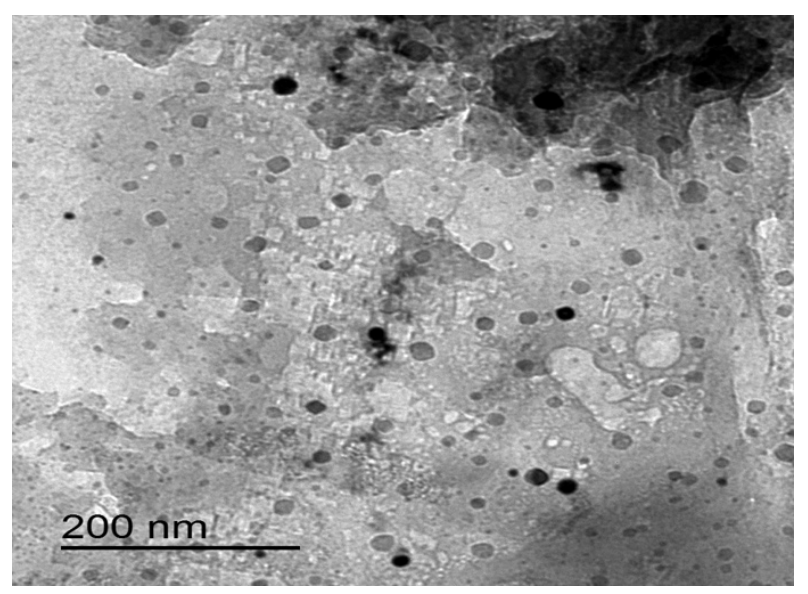

(h)

Figure 8: $50 \mathrm{~nm}, 100 \mathrm{~nm}$ and $200 \mathrm{~nm}$ TEM micrograph of chicory extract ash

\section{4- conclusion:}

Chicory is a natural growing plant rich in minerals and vitamins. According to analyses conducted we found many elements in nanoparticle size such as $\mathrm{Na}, \mathrm{K}, \mathrm{Ca}$, $\mathrm{Mg}, \mathrm{Zn}$ and other elements. Data obtained revealed that the crystalline nature of nanoparticles was confirmed by X-ray crystallography. The XRD pattern indicates that the only mineral in its composition is KCL (sylvite) with average crystallite size $20 \mathrm{~nm}$, the result crystal size shown had cubic structure. The TEM analysis shows that the chicory extract ash has an appropriate diameter in the range of the nano scale.The $50 \mathrm{~nm}$ of TEM micrograph of chicory extract ash,which explains nanoparticles with an average grain size of about $(3.15-20.73) \mathrm{nm}$, the $100 \mathrm{~nm}$ of TEM micrograph of chicory extract ash, which explains nanoparticles with an average grain size of about $(5.12-22.18) \mathrm{nm}$. So we expect that the nanofluid that we prepared for cooling purposes of Photovoltaic solar cell and improving it's performance.

\section{Nomenclature}

$\begin{array}{llll}\mathrm{Ag} & \text { Silver } & \mathrm{Al} & \text { Aluminium } \\ \mathrm{B} & \text { Boron } & \mathrm{Ba} & \text { Barium } \\ \mathrm{Bi} & \text { Bismuth } & \mathrm{Ca} & \text { Calcium } \\ \mathrm{Cd} & \text { Cadmium } & \mathrm{Co} & \text { Cobalt } \\ \mathrm{Cr} & \text { Chromium } & \mathrm{Cu} & \text { Copper } \\ \mathrm{Fe} & \text { iron } & \mathrm{Ga} & \text { gallium }\end{array}$




\begin{tabular}{llll}
\hline \hline $\mathrm{In}$ & Indium & $\mathrm{K}$ & potassium \\
$\mathrm{Li}$ & Lithium & $\mathrm{Mg}$ & Magnesium \\
$\mathrm{Mn}$ & Manganese & $\mathrm{N}$ & Nitrogen \\
$\mathrm{Na}$ & Sodium & $\mathrm{Pb}$ & plumbum \\
$\mathrm{Sr}$ & Strontium & $\mathrm{Ti}$ & Thallium \\
$\mathrm{Zn}$ & Zinke & &
\end{tabular}

\section{5- REFERNCES:}

[1]Al-Snafi, Ali. Medical importance of Cichorium intybus - A review. IOSR Journal of Pharmacy. 2016. 6. 41-56.

[2] Afzal, S., N. Afzal, Awan M.R., Khan T.S., Gilani A., Khanum R.and Tariq S.. J. Ayub Med. Coll. Abbotabad 2009;21(1): 52-57.

[3] Street RA, Sidana J, Prinsloo G. Cichorium intybus: Traditional Uses, Phytochemistry, Pharmacology, and Toxicology. Evid Based Complement Alternat Med. 2013;2013:579319. doi:10.1155/2013/579319

[4] Cichota, Rogerio \& McAuliffe, Russell \& Lee, Julia \& Minneé, E. \& Martin, Kirsty \& Brown, Hamish \& Moot, D. \& Snow. Forage chicory model: Development and evaluation. Field Crops Research, Val. 2020, 246. 107633. 10.1016/j.fcr.2019.107633.

[5] Bremer, K.; Anderberg, A.A. Asteraceae: Cladistics and Classification; Timber Press: Portland, OR, USA, 1994.

[6] Ramezan, Yousef. Investigation of inulin extraction from roots of chicory (Cichorium intybus L.). 2018. 9.

[7] Carazzone C, Mascherpa D, Gazzani G, Papetti A. Identification of phenolic constituents in red chicory salads (Cichorium intybus) by high-performance liquid chromatography with diode array detection and electrospray ionisation tandem mass spectrometry. Food Chem. 2013;138(2):1062-71.

[8] Hedrick U, Sturtevant LE. Sturtevant's Edible Plants of the World. New York, NY; Dover; 1972.

[9] Launert E. The Hamlyn Guide to Edible and Medicinal Plants of Northern England. London, UK; Hamlyn; 1981.

[10] Grieve, Maud. A modern Herbal : the medicinal, culinary, cosmetic and economic properties, cultivation and folk-lore of herbs, grasses,fungi, shrubs \& trees, with all their modern scientific uses / Maud Grieve, with an introduction by the editor, Mrs. C. F. Leyel. SERBIULA (sistema Librum 2.0). 2020. 
[11] Hitova, Anna \& Melzig, Matthias. Cichorium intybus L.. Zeitschrift fur Phytotherapie. 2014.35. 198-202. 10.1055/s-0034-1371731.

[12] Jurgoński A, Juśkiewicz J, Zduńczyk Z, Król B. Caffeoylquinic acid-rich extract from chicory seeds improves glycemia, atherogenic index, and antioxidant status in rats. Nutrition. 2012;28(3):300-6.

[13] Skoog, D.A., Holler, F.J. and Crouch, S.R. Principles of Instrumental Analysis. Sixth Edition, Brooks Cole, Belmont, 2007.

[14] Scherrer P. "Bestimmung der Größe und der inneren Struktur von Kolloidteilchen mittels Röntgenstrahlen", Nachr. Ges. Wiss. Göttingen (1918), 26:98-100.

[15] J.I. Langford and Wilson, A.J.C."Scherrer after Sixty Years: A Survey and Some New Results in the Determination of Crystallite Size", J. Appl. Cryst. 1978, 11:102-113.

[16] Karnovsky, M.J. A formaldehyde-glutaraldehyde fixative of high osmolality for use in electron-microscopy. Journal of Cell Biology, 1965, 27:137-138.

[17] Koleva, V., Chilev, Ch., Penchev, I., Simeonov, E., Extracting of biologically active substances from Cichorium intybus, Scientific works of UFT: "Food science, engineering and technologies". UFT Academic Publishing House, Plovdiv, 2012; 198200

[18] Al-Shamani, A. N., Nanofluids for improved efficiency in cooling solar collectors A review, Renewable and Sustainable Energy Reviews 2014; 38: 348-367.

[19] Wong, K.V.,DeLeonO.Applications of nanofluids: current and future.Adv Mech Eng 2010; 2010:1-11. 